\title{
Effects of $W$ ater Stress and Temperature on Germination of True Mountainmahogany
}

\section{J. R. PIATT}

Highlight: The effects of five levels of available water and four constant temperature regimes upon the germination of two ecotypic collections of true mountainmahogany (Cercocarpus montanus Raf.) were investigated. Results indicate that moisture stress significantly decreases both the rate and final amount of germination in this species. The amount of moisture stress required to cause these decreases was found to be dependent upon both the seed source and the temperature. Temperature was found to be more important in determining the rate than the amount of germination.

Of all environmental factors affecting the ecology of terrestrial vegetation, water supply and temperature are probably the most important (Krebs, 1972). Although a substantial number of investigations have been conducted concerning these factors, relatively few of them deal with the germination of forage shrubs (Springfield, 1966, 1968). True mountainmahogany (Cercocarpus montanus Raf.) has long been known to be a valuable source of forage for both wildlife and domestic livestock. Although two investigators (Smith, 1971; Heit, 1970) have reported on the effects of temperature on the germination of this species, the interaction of temperature and moisture stress has not been documented; and it is to this question that this report is addressed.

Seeds for this study were collected from two locations in New Mexico and stored in paper bags at room temperature $\left(20-22^{\circ} \mathrm{C}\right)$ until the study was conducted in April, 1972. A collection was made in 1969 on Pinabetosa Mesa, an oak-mountainmahogany site (Daubenmire, 1943) at $8,000 \mathrm{ft}$ elevation near the town of Coyote. A second collection was made in 1970 from a group of plants near the northern edge of Santa $\mathrm{Fe}$, at $7,300 \mathrm{ft}$ elevation, in the pinyon-juniper type.

\section{Materials and Methods}

Moisture stresses were established through the use of aqueous solutions of mannitol. Sufficient mannitol was added to distilled water to lower the water potential to one of the following osmotic potentials: $-0.3,-3.0,-7.0,-11.0$ or -15.0 atmospheres. Amount of mannitol required to produce these

Author is a graduate student, Department of Biology, University of New Mexico, Albuquerque.

The author gratefully acknowledges the review of the manuscript by C. R. Wyer and H. W. Springfield.

Manuscript received February 21, 1975. water potentials were calculated in accordance with the van't Hoff equation (Salisbury and Ross, 1969, p 66-67).

Bulk samples of seeds underwent an initial moist, cold $\left(3^{\circ} \mathrm{C}\right)$ pretreatment for 40 days prior to the start of the experiment to overcome dormancy and promote rapid and complete germination (Forest Service, 1948; Heit, 1970). The seeds were germinated in petri dishes atop two layers of standard germination blotters. Fifty seeds were placed in each dish, and the dishes were randomly arranged in factorial design with three replications per treatment. Fifteen milliliters of the appropriate solutions were added at the beginning of the experiment; evaporation over the 28-day-long experiment was minimal.

Temperatures used in this experiment were $10,20,25$, and $30^{\circ} \mathrm{C}$. All tests were conducted in environmental chambers (Lab-Line Mark I) programmed for constant temperatures; fluctuations never exceeded $\pm 2{ }^{\circ} \mathrm{C}$. Except when counts of germinated seeds were conducted, the seeds were kept in constant darkness. Preliminary tests have indicated that germination of this species is neither positively or negatively affected by light.

Seeds were considered to have germinated when the radicle had penetrated the seed coats, grown for a minimum of 1.0 $\mathrm{cm}$, and had a meristem which appeared normal (they did not exhibit dark coloration, curvature at the tip, lack of root hairs, etc.). Germinated seeds were removed from the petri dishes.

Counts of germinated seeds were taken daily for the first 2 weeks of the experiment and then at 2- to 3-day intervals.

Germination data underwent arcsin transformation prior to statistical analysis. Such transformations are necessary as the percentage germination data were not normally distributed and would thus violate the assumptions of analysis of variance upon which the statistical procedures used are based (Sokal and Rohlf, 1969).

\section{Results}

The overall mean germination of the Santa Fe collection (40.6\%) was significantly greater $(p<0.05)$ than that of the Pinabetosa Mesa collection (30.5\%). The interactions of a source by temperature and source by osmotic pressure were not significant.

Table 1 illustrates the amount of germination which had occurred at the end of the experiment. The Santa Fe collection proved to be extremely sensitive to moisture stress: each decrease in water potential was found to result in a significant decrease in the final germination percentages. In this ecotype temperature is of comparatively less importance 
Table 1. Effects of moisture stress and temperature on the germination percentage ${ }^{1}$ of true mountainmahogany after 28 days.

\begin{tabular}{lllllll}
\hline & \multicolumn{6}{c}{ Osmotic pressure in atmospheres } \\
\cline { 2 - 7 } $\begin{array}{l}\text { Tempera- } \\
\text { ture }\left({ }^{\circ} \mathrm{C}\right)\end{array}$ & -0.3 & -3.0 & -7.0 & -11.0 & -15.0 & Mean \\
\hline
\end{tabular}

Santa Fe

collection

$\begin{array}{clllrll}10 & 78.0 \mathrm{a}^{2} & 42.7 \mathrm{~b} & 34.7 \mathrm{c} & 1.3 \mathrm{~d} & 1.3 \mathrm{~d} & 31.6 \mathrm{AB}^{2} \\ 20 & 86.0 \mathrm{a} & 73.3 \mathrm{a} & 62.7 \mathrm{bc} & 46.0 \mathrm{c} & 2.7 \mathrm{~d} & 54.1 \mathrm{~A} \\ 25 & 81.3 \mathrm{a} & 78.0 \mathrm{a} & 58.0 \mathrm{~b} & 22.7 \mathrm{c} & 6.7 \mathrm{c} & 49.3 \mathrm{~A} \\ 30 & 72.7 \mathrm{a} & 47.3 \mathrm{~b} & 10.0 \mathrm{c} & 6.7 \mathrm{c} & 0.7 \mathrm{c} & 27.5 \mathrm{~B} \\ \text { Mean } & 79.5 \mathrm{~A}^{2} & 60.3 \mathrm{~B} & 41.3 \mathrm{C} & 19.2 \mathrm{D} & 2.8 \mathrm{E} & \end{array}$

Pinabetosa Mesa

collection

\begin{tabular}{cllrrrr}
10 & $65.3 \mathrm{a}^{2}$ & $30.0 \mathrm{~b}$ & $8.0 \mathrm{bc}$ & $0.7 \mathrm{c}$ & $0.0 \mathrm{c}$ & $20.8 \mathrm{~B}^{2}$ \\
20 & $78.7 \mathrm{a}$ & $75.3 \mathrm{a}$ & $28.7 \mathrm{~b}$ & $10.7 \mathrm{c}$ & $1.3 \mathrm{c}$ & $38.9 \mathrm{~A}$ \\
25 & $82.7 \mathrm{a}$ & $84.0 \mathrm{a}$ & $61.3 \mathrm{~b}$ & $13.3 \mathrm{c}$ & $5.3 \mathrm{c}$ & $49.3 \mathrm{~A}$ \\
30 & $42.7 \mathrm{a}$ & $20.0 \mathrm{~b}$ & $1.3 \mathrm{c}$ & $0.7 \mathrm{c}$ & $0.0 \mathrm{c}$ & $12.9 \mathrm{~B}$ \\
Mean & $67.4 \mathrm{~A}^{2}$ & $52.3 \mathrm{~A}$ & $24.8 \mathrm{~B}$ & $6.4 \mathrm{BC}$ & $1.6 \mathrm{C}$ & \\
\hline
\end{tabular}

${ }^{1}$ Data underwent an arcsin transformation prior to analysis by

Duncan's new multiple range test.

${ }^{2}$ Values within a row or means not followed by the same letter are significantly different at the 0.05 level.

in determining the amount of germination which will occur. Thirty degrees was clearly inhibitory, although statistically equivalent to $10^{\circ} \mathrm{C}$. The "optimum" temperature for germination of this collection appears to be approximately $20^{\circ} \mathrm{C}$.

The Pinabetosa Mesa collection proved to be more sensitive to temperature extremes, with both the $10^{\circ}$ and the $30^{\circ}$ temperatures significantly inhibiting the amount of germination. The "optimum" temperature for germination of this collection is approximately $25^{\circ} \mathrm{C}$. This collection was not as sensitive to moisture stress as was the Santa $\mathrm{Fe}$ collection since a significant decrease in germination did not occur until the water potential decreased to -7.0 atmospheres.

Detailed analysis of the data was required when it was found that the interaction of temperature $X$ osmotic pressure was highly significant $(p<0.01)$. It appears that a moisture stress is less deleterious at "optimum" temperatures. Thus, in both ecotypes an osmotic pressure of $-3.0 \mathrm{~atm}$ is inhibitory at $10^{\circ}$ and $30^{\circ}$ but not at $20^{\circ}$ or $25^{\circ} \mathrm{C}$.

Several authors have presented graphical evidence that moisture stress not only decreases the amount of germination, but also decreases the rate of germination (McGinnies, 1960; Springfield, 1966, 1968; Tapia and Schmutz, 1971). To more accurately describe this phenomenon, a series of simple linear regressions was calculated (Table 2), and the regression coefficients statistically compared by use of the technique of Sokal and Rohlf (1969, p. 451). Although data presented in Table 1 was that found at the conclusion of the 28-day-long experiment, regressions were calculated for the first 7 days of the experiment. Justification for using this shorter time period lies in the fact that over this period cocfficients of determination $\left(R^{2}\right)$ values were at a maximum (range of 0.81 to 0.98$)$ and $F$-values were all highly significant $(p<0.01)$. Thus the regression equations explain the observed trends more adequately than do regressions calculated for either longer or shorter time intervals. In addition, a more realistic approximation of field conditions could be presented: constant temperature and/or constant moisture stresses are not found over 28-day periods in the field.

Germination at -11.0 and -15.0 atm of moisture stress was insufficient to fit significant regressions.
Table 2. Comparisons of the rate ${ }^{1}$ of germination of true mountainmahogany under different moisture stresses and temperatures.

\begin{tabular}{|c|c|c|c|}
\hline \multirow{2}{*}{$\begin{array}{l}\text { Tempera- } \\
\text { ture }\left({ }^{\circ} \mathrm{C}\right)\end{array}$} & \multicolumn{3}{|c|}{ Osmotic pressure in atmospheres } \\
\hline & -0.3 & -3.0 & -7.0 \\
\hline \multicolumn{4}{|l|}{$\begin{array}{l}\text { Santa Fe } \\
\text { collection }\end{array}$} \\
\hline $\begin{array}{l}10 \\
20 \\
25 \\
30\end{array}$ & $\begin{array}{c}1.67 \mathrm{a} \mathrm{C}^{2} \\
13.09 \text { a A } \\
12.29 \text { a A } \\
8.74 \text { a B }\end{array}$ & $\begin{array}{r}0.40 \mathrm{~b} \mathrm{C} \\
11.64 \text { a A } \\
12.24 \text { a A } \\
5.27 \text { b B }\end{array}$ & $\begin{array}{c}0.31 \text { b } \\
6.50 \text { b } \\
\underset{3}{5.41} \text { b }\end{array}$ \\
\hline \multicolumn{4}{|l|}{$\begin{array}{l}\text { Pinabetosa Mesa } \\
\text { collection }\end{array}$} \\
\hline $\begin{array}{l}10 \\
20 \\
25 \\
30\end{array}$ & $\begin{array}{c}3.10 \mathrm{a} \mathrm{B}^{2} \\
13.46 \mathrm{a} \mathrm{A} \\
12.02 \mathrm{a} \mathrm{A} \\
5.52 \mathrm{a} \mathrm{B}\end{array}$ & $\begin{array}{r}1.22 \mathrm{~b} \mathrm{C} \\
7.32 \mathrm{~b} \mathrm{~B} \\
11.12 \mathrm{a} \mathrm{A} \\
2.60 \mathrm{~b} \mathrm{C}\end{array}$ & $\begin{array}{c}3 \\
0.91 \text { c B } \\
\underset{3}{6.13} \text { b A }\end{array}$ \\
\hline
\end{tabular}

${ }^{1}$ Values are the regression coefficients of linear regressions from the first 7 days of the experiment.

${ }^{2}$ In a collection, values within a row or column not followed by the same letter are significantly different at the 0.05 level. Lower case letters refer to values within a row.

${ }^{3}$ Insufficient germination to fit significant regression lines.

The overall pattern found in Table 2 is quite similar to that first noted in Table 1 . In general, moist ure stresses at favorable temperatures are less inhibitory than at extreme temperatures. The most predominant trend is a decrease in the rate of germination as moisture stress becomes greater. In contrast to the germination data, temperature per se is of greater importance when the rate of germination is considered. Extreme temperatures significantly decrease the rate of germination, but the amount of the decrease is dependent upon the seed collection. Here, the Santa Fe collection shows a larger decrease in the rate of germination at $10^{\circ}$ than does the Pinabetosa Mesa collection.

\section{Discussion}

Woodmansee (1969) found that germination of this species in situ was very erratic. He noted that successful establishment of seedlings in central New Mexico occurred only when seeds germinated in areas which were shaded throughout most of the day. He hypothesizes that this differential survival is related to the more favorable moisture conditions of such microhabitats. Results presented herein suggest that his observations may be the result of differences in the amount of germination in different microhabitats in addition to differential patterns of mortality.

Results presented are of importance to management personnel who wish to re-establish this species on depleted ranges. It is now apparent that the germination of this species is strongly affected by both moisture stress and temperature individually and by the rather complex interaction of these factors. It should also be noted that different sources of seeds respond differently to these conditions. These source differences may represent ecotypic adaptations to the environmental conditions associated with the sites they inhabit.

\section{Literature Cited}

Daubenmire, R. F. 1943. Vegetation zonation in the Rocky Mountains. Bot. Rev. 9:323-393.

Forest Service. 1948. Woody-plant seed manual. U.S. Dep. Agr. Misc. Pub. 654. 416 p. 
Heit, C. E. 1970. Germinative characteristics and optimum methods for twelve western shrub species. Proc. Ass. Otfic. Seed Anal. 60:197-205

Krebs, C. J. 1972. Ecology: the experimental analysis of distribution and abundance. Harper and Row, Publ. 694 p.

McGinnies, W. J. 1960. Effects of moisture stress and temperature on germination of six range grasses. Agron. J. 52:159-162.

Salisbury, F. B., and C. Ross. 1969. Plant physiology. Wadsworth Publ. Co., Inc. $747 \mathrm{p}$.

Smith, D. R. 1971. Growth responses of true mountainmahogany (Cercocarpus montanus) on four soil types within the front range of Colorado. PhD Thesis. Utah State Univ. 206 p.
Sokal, R. R., and F. J. Rohlf. 1969. Biometry: the principles and practice of statistics in biological research. W. H. Freeman and Co. $776 \mathrm{p}$.

Springfield, H. W. 1966. Germination of fourwing saltbush seeds at different levels of moisture stress. Agron. J. 58:149-150.

Springfield, H. W. 1968. Germination of winterfat seeds under different moisture stresses and temperatures. J. Range Manage. 21:314-316.

Tapia, C. R., and E. M. Schmutz. 1971. Germination responses of three desert grasses to moisture stress and light. J. Range Manage. 24:292-295.

Woodmansee, R. G. 1969. Natural reproduction of Eurotia lanata, Atriplex canescens, Cercocarpus montanus, and Cowania mexicana in New Mexico. MS Thesis. Univ. of New Mexico. 77 p. 